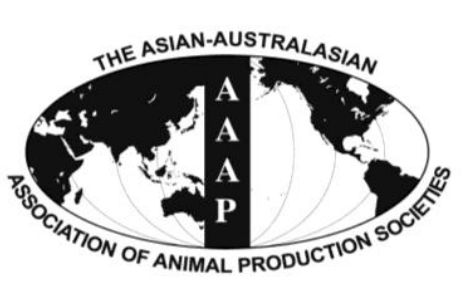

Open Access

Asian Australas. J. Anim. Sci.

Vol. 27, No. 3 : 375-382 March 2014

http://dx.doi.org/10.5713/ajas.2013.13030

www.ajas.info

pISSN 1011-2367 elSSN 1976-5517

\title{
Effects of Two Herbal Extracts and Virginiamycin Supplementation on Growth Performance, Intestinal Microflora Population and Fatty Acid Composition in Broiler Chickens
}

\author{
Suriya Kumari Ramiah ${ }^{1}$, Idrus Zulkifli ${ }^{1,2, *}$, Nordiana Asyikin Abdul Rahim ${ }^{2}$, \\ Mahdi Ebrahimi ${ }^{3}$, and Goh Yong Meng ${ }^{1,3}$ \\ Institute of Tropical Agriculture, Universiti Putra Malaysia, 43400 UPM Serdang, Selangor, Malaysia
}

\begin{abstract}
The competency of garlic and pennywort to improve broiler chicken growth and influence intestinal microbial communities and fatty acid composition of breast meat were studied. Two hundred forty, "day-old" chicks were randomly allocated to 4 treatment groups consisting of 6 replications of 10 chicks in each pen. The groups were assigned to receive treatment diets as follows: i) basal diet (control), ii) basal diet plus $0.5 \%$ garlic powder (GP), iii) basal diet plus $0.5 \%$ pennywort powder (PW) and iv) $0.002 \%$ virginiamycin (VM). Birds were killed at day 42 and intestinal samples were collected to assess for Lactobacillus and Escherichia coli. The pectoralis profundus from chicken breast samples was obtained from 10 birds from each treatment group on day 42 and frozen at $-20^{\circ} \mathrm{C}$ for further analyses. Fatty acid profile of breast muscles was determined using gas liquid chromatography. Feed intake and weight gain of broilers fed with GP, PW, and VM were significantly higher $(\mathrm{p}<0.05)$ compared to control. Feeding chicks GP, PW, and VM significantly reduced Escherichia coli count $(\mathrm{p}<0.05)$ while Lactobacillus spp count were significantly higher $(\mathrm{p}<0.05)$ in the gut when compared to control group on day 42. Supplemented diet containing pennywort increased the C18:3n-3 fatty acid composition of chickens' breast muscle. Garlic and pennywort may be useful in modulating broiler guts as they control the enteropathogens that help to utilize feed efficiently. This subsequently enhances the growth performances of broiler chickens. (Key Words: Broiler Chicken, Garlic, Pennywort, Growth Performances, Microbial Population, Fatty Acid Composition)
\end{abstract}

\section{INTRODUCTION}

The use of antibiotic growth promoters (AGP) has been widely practiced in animal production for decades worldwide. The benefits of AGP in improving production efficiency of broiler chickens are well established (Miles et al., 2006). However, AGP may also leave residue in animal products such as meat, milk and egg (Nisha, 2008).

There is a growing interest in herbal plants as

\footnotetext{
* Corresponding Author: Idrus Zulkifli. Tel: +60-3-89471042, Fax: +60-3-89381612, E-mail: zulidrus@upm.edu.my

${ }^{1}$ Institute of Tropical Agriculture, Universiti Putra Malaysia, 43400 UPM Serdang, Selangor, Malaysia.

${ }^{2}$ Faculty of Agriculture, Universiti Putra Malaysia, 43400 UPM Serdang, Selangor, Malaysia.

3 Faculty of Veterinary Medicine, Universiti Putra Malaysia, 43400 UPM Serdang, Selangor, Malaysia.

Submitted Jan. 11, 2013; Accepted Aug. 19, 2013; Revised Oct. 23, 2013
}

alternatives to AGP. The benefits of herbal feed additives in improving growth performance and nutrient digestibility, and reducing pathogens have been reported (Zulkifli et al., 2012).

Garlic bulb, paste, oil, powder, husk and leaves may influence the performance of farm animals (Qureshi et al., 1983). The functions of garlic are mainly attributed to the bioactive components, including sulfur-containing compounds such as alliin, diallylsulphides and allicin (Amagase et al., 2001). Allicin and its derivatives have been shown to be a larvicidal and bacteriostatic, active against both Gram positive or Gram negative organisms as well as fungi such as Candida albicans and viruses including influenza viruses (Chang and Cheong, 2008). Kumar and Berwal (1998) tested antibacterial activity of fresh garlic bulbs against the potent food pathogens; Staphylococcus aureus, Escherichia coli (E. coli), Salmonella typhi and Listeria monocytogenes. They found E. coli is the most

Copyright $@ 2014$ by Asian-Australasian Journal of Animal Sciences This is an open-access article distributed under the terms of the Creative Commons Attribution Non-Commercial License (http://creativecommons.org/licenses/by-nc/3.0/) which permits unrestricted non-commercial use, distribution, and reproduction in any medium, provided the original work is properly cited. 
sensitive among all pathogen tested to the effect of garlic.

Pennywort, Centella asiatica or pegaga, is closely related to the species Hyrocotyle (Hussin et al., 2007). It is known for its reputation as a wound healing agent and brain stimulant (Oyedeji et al., 2005). The chemical composition of pennywort has a very important role in medicinal and nutriceutical applications. These applications are most likely due to its biologically active constituents of triterpenes namely asiatic acid and asiaticoside (Inamdar et al., 1996). Noraharaini et al. (2011) reported that the bioactive compounds of pennywort have antibacterial properties against Helicobacter pylori, Staphyloccocus aurues, E. coli and Pseudomonas aeroginosa.

Poultry meat has many desirable nutritional characteristics such as low lipid and relatively high concentration of polyunsaturated fatty acids (Bourre, 2005). Modification of meat fatty acid composition through feeding provided the best results in single-stomached poultry (Wood et al., 1999). Earlier study demonstrated that dietary supplementation of garlic could reduce serum cholesterol in broilers (Qureshi et al., 1983) and laying hens (Yalcin et al., 2007). To the authors' best knowledge, there is limited information on the effects of pennywort on the growth performance and fatty acid composition of broiler meat.

This present study was designed to compare the effects of dietary supplementation of garlic, pennywort and virginiamycin on growth performance, gut microflora and meat fatty acid composition in commercial broiler chickens.

\section{MATERIALS AND METHODS}

\section{Animal welfare}

This study was undertaken following the guidelines of the Research Policy of the Universiti Putra Malaysia on animal ethics.

\section{Source and preparation methods for diet}

Garlic bulbs and pennywort plant were purchased from a local wholesale market in Selangor, Malaysia. They were coarsely chopped and dried in an oven at $50^{\circ} \mathrm{C}$ until constant weight. Dried materials were ground into powder using a Wiley mill through a 1-mm screen (Thomas Wiley Cutting Mill Model 4 Thomas Scientific, Swedeboro, NJ, USA) and stored at $4{ }^{\circ} \mathrm{C}$ until further use.

\section{Experimental birds and diets}

A total of 240 day-old male broiler chicks (Cobb 500) were obtained from a local hatchery. Upon arrival, the chicks were individually wing-tagged, weighed and randomly assigned into four treatments group. Each treatment group had six replicates of 10 birds. The cages were three-tiered and each block consisted of six cages. The cages were in a conventional open-sided house with cyclic temperatures (minimum, $24^{\circ} \mathrm{C}$; maximum, $34^{\circ} \mathrm{C}$ ). The relative humidity was between $80 \%$ to $90 \%$. Feed and water were provided ad libitium and lighting was continuous. The chicks were vaccinated against Newcastle disease on day 7 and 21. Commencing from day one, six replicate cages containing 10 chicks were assigned to each of the four dietary treatments, giving a total of 24 pens. The dietary treatments were:

i) Basal diet (Control)

ii) Basal diet plus $0.5 \%$ garlic powder (GP)

iii) Basal diet plus $0.5 \%$ pennywort powder $(\mathrm{PW})$ and

iv) Basal diet plus $0.002 \%$ virginiamycin (Pfizer, USA) (VM)

The chickens were fed starter and finisher diets from day 0 to 21 and day 22 to 42 respectively. The diets were in mash form. The composition of experimental diets was formulated to meet or exceed NRC (1994) recommendations (Table 1). Feed intake and BW were recorded weekly and feed conversion ratios (FCR) (feed/gain) were calculated.

\section{Bacterial count}

On day 42, 10 birds from each treatment group were randomly selected (more than one bird were sampled from some replicate cages) and were slaughtered. Their small intestines (from the distal end of the duodenum to the ileocaecal junction) were removed immediately and placed in sterile. All the birds (including those not selected) appeared healthy at the point of sampling. One gram of faecal sample from each pen was then diluted with $9 \mathrm{~mL}$ of $1 \%$ peptone broth (Becton, Dickinson and Co.) and homogenized. Viable counts of bacteria in the faecal samples were then conducted by plating serial 10 -fold dilutions (in $1 \%$ peptone solution) onto MacConkey agar plates (Difco Laboratories, Detroit, MI, USA) and lactobacilli medium III agar plates (Medium 638; DSMZ, Braunschweig, Germany) to isolate Escherichia coli and Lactobacillus, "respectively". Escherichia coli was counted on the eosin-methylene blue (EMB) agar and incubated for $24 \mathrm{~h}$ at $37^{\circ} \mathrm{C}$. Lactobacillus was counted on the Rogosa agar and incubated for 24 to $72 \mathrm{~h}$ at the same temperature. Colonies with green metallic colour considered as Escherichia coli while the white colour is Lactobacillus. The microbial counts were determined as colony forming units (cfu) per gram of samples.

\section{Lipid extraction}

Pectoralis profundus of chicken breast samples were obtained from 10 birds (those that were used for bacterial count) randomly selected from each treatment group on day 42 and frozen at $-20^{\circ} \mathrm{C}$ for further analyses. Total fatty acid 
Table 1. Ingredient and nutrient composition of diets

\begin{tabular}{|c|c|c|}
\hline \multirow[b]{2}{*}{ Ingredient $(\%)$} & \multicolumn{2}{|c|}{ Experimental diets } \\
\hline & $\begin{array}{c}\text { Starter } \\
\text { (1 to } 21 \text { days) }\end{array}$ & $\begin{array}{c}\text { Finisher } \\
\text { (22 to } 42 \text { days) }\end{array}$ \\
\hline Corn (Crude protein: $8.5 \%$ ) & 54.29 & 58.25 \\
\hline $\begin{array}{l}\text { Soybean meal } \\
\text { (Crude protein: } 41.6 \%)\end{array}$ & 34.20 & 28.86 \\
\hline Fish oil & 5.35 & 5.75 \\
\hline Crude palm oil & 2.55 & 4.05 \\
\hline DiCalcium phosphate & 1.09 & 0.89 \\
\hline Limestone & 1.01 & 0.84 \\
\hline Fine salt & 0.39 & 0.26 \\
\hline Mineral premix ${ }^{1}$ & 0.30 & 0.30 \\
\hline Vitamin premix $^{1}$ & 0.30 & 0.30 \\
\hline Lysine & 0.34 & 0.33 \\
\hline DL-methionine & 0.18 & 0.17 \\
\hline \multicolumn{3}{|l|}{ Analysed nutrient $(\%)$} \\
\hline Crude protein & 22 & 20 \\
\hline $\mathrm{ME} \mathrm{kcal} / \mathrm{kg}$ & 3,000 & 3,150 \\
\hline Crude fiber & 3.73 & 3.42 \\
\hline Crude fat & 5.39 & 7.04 \\
\hline \multicolumn{3}{|l|}{ Total saturated fat } \\
\hline $\mathrm{SFA}^{2}$ & 50.44 & 52.03 \\
\hline $\mathrm{UFA}^{3}$ & 49.56 & 47.97 \\
\hline MUFA $^{4}$ & 36.85 & 36.79 \\
\hline PUFAn- $3^{5}$ & 1.09 & 0.42 \\
\hline PUFAn- $6^{6}$ & 11.62 & 10.76 \\
\hline n-6:n-3 ratio $^{7}$ & 10.68 & 25.66 \\
\hline UFA:SFA & 0.98 & 0.92 \\
\hline PUFA:SFA ratio & 0.25 & 0.21 \\
\hline
\end{tabular}

${ }^{1}$ Premixes contributed the following nutrients per kilogram of complete feed: vitamin $\mathrm{A}, 2,300 \mathrm{IU}$; vitamin $\mathrm{D}_{3}$, $400 \mathrm{IU}$; vitamin $\mathrm{E}, 1.8 \mathrm{mg}$; vitamin $\mathrm{B}_{12}, 3.5 \mathrm{mg}$; riboflavin, $1.4 \mathrm{mg}$; panthotenic acid, $2 \mathrm{mg}$; nicotinic acid, $7 \mathrm{mg}$; pyridoxine, $0.25 \mathrm{mg}$; folic acid, $0.15 \mathrm{mg}$; menadione, $0.3 \mathrm{mg}$; thiamin, $0.15 \mathrm{mg}$; manganese oxide, $35 \mathrm{mg}$; ferrous sulfate $35 \mathrm{mg}$; zinc oxide, $30 \mathrm{mg}$; copper sulfate, $60 \mathrm{mg}$; cobalt carbonate, $5 \mathrm{mg}$; potassium iodine, $0.6 \mathrm{mg}$; selenium vanadate, $0.09 \mathrm{mg}$. Based on NRC (1994) feed composition table.

${ }^{2} \mathrm{SFA}=$ sum of $\mathrm{C} 10: 0+\mathrm{C} 12: 0+\mathrm{C} 14: 0+\mathrm{C} 15: 0+\mathrm{C} 16: 0+\mathrm{C} 17: 0+\mathrm{C} 18: 0$.

${ }^{3} \mathrm{UFA}=$ sum of $\mathrm{C} 14: 1+\mathrm{C} 16: 1+\mathrm{C} 17: 1+\mathrm{C} 18: 1 \mathrm{n}-9+\mathrm{C} 18: 2+\mathrm{C} 18: 3$.

${ }^{4}$ MUFA $=$ sum of $\mathrm{C} 14: 1+\mathrm{C} 16: 1+\mathrm{C} 17: 1+\mathrm{C} 18: 1 \mathrm{n}-9$.

${ }^{5}$ PUFA $n-3=$ sum of $\mathrm{C} 18: 3 \mathrm{n}-3$.

${ }^{6}$ PUFA $\mathrm{n}-6=$ sum of $\mathrm{C} 18: 2 \mathrm{n}-6$

${ }^{7} n-6: n-3=$ sum of $(C 18: 2 n-6) /$ sum of $(C 18: 3 n-3)$.

from meat samples were extracted using a chloroformmethanol as described by Folch et al. (1957) with some modification by Ebrahimi et al. (2012). The total fatty acid was dried under stream of $\mathrm{N}_{2}$ gas and FAME was prepared by methylation of the fatty acids using methanolic $\mathrm{KOH}$ following boron trifuoride $\left(\mathrm{BF}_{3}, 14 \%\right.$ in methanol) after the initial KOH hydrolysis (Cruz et al., 2013).

\section{Fatty acid analysis}

Fatty acid methyl esters were separated and quantified by gas-liquid chromatography (Model 7890A, Agilent
Technologies, USA) using a $30 \mathrm{~m} \times 0.32 \mathrm{~mm}$ i.d. capillary column (SP-2330, Supelco, Inc., Bellefonte, PA, USA). The hydrogen was used as the carrier gas at $40 \mathrm{~mL} / \mathrm{min}$. The injector temperature was programmed at $240^{\circ} \mathrm{C}$ and the detector temperature was $250^{\circ} \mathrm{C}$. The column temperature program started to run at $140^{\circ} \mathrm{C}$, for $2 \mathrm{~min}$, warmed to $158^{\circ} \mathrm{C}$ at $1^{\circ} \mathrm{C} / \mathrm{min}$, held for $28 \mathrm{~min}$, warmed to $220^{\circ} \mathrm{C}$ at $1^{\circ} \mathrm{C} / \mathrm{min}$ and then held for $20 \mathrm{~min}$ to achieve satisfactory separation. The identification of the peaks was made by comparison of equivalent chain lengths with those of authentic fatty acid methyl esters (37 Component FAME mix, Supelco, Bellefonte, PA). Peak areas were determined automatically using the Agilent gas chromatography chemstation software (Agilent Technologies, USA). The fatty acid concentrations are expressed as percentage of the sum of total identified peaks measured in each sample.

\section{Statistical analysis}

All data presented in this paper are the actual untransformed data except log-transformed data used for bacterial count when necessary to best approximate the normal distribution. Except for mortality, all data were analysed using the one-way ANOVA. Mortality data were analysed by chi-square test. Significant means were then elucidated using the Duncan multiple range tests. All statistical tests were conducted at $95 \%$ confidence level using SAS program (Version 6.0, SAS Institute Inc, 2003). The results were expressed as means with pooled of standard error of mean (SEM).

\section{RESULTS}

Mean BW, feed intake and feed efficiency are shown in Table 2. Diet had no significant effect ( $p>0.05)$ on BW of chicks at 7 and 14 days of age. However, on days 21, 35, and 42, birds fed GP, PW, and VM had significantly greater $(\mathrm{p}<0.05)$ BW than controls. On day 28, the BW of the control chickens were less than PW and VM but not significantly different $(p=0.008)$ from those of the GP. The ADG was not significantly different in any treatment diets $(p=0.419)$ at starter phase. However, data at the finisher phase and overall trial showed that the ADG of GP, PW and VW were significantly different higher $(\mathrm{p}<0.05)$ compared to control group. Irrespective of diet, feed intake during the first 3 weeks was not significantly different $(p>0.05)$. Feeding birds with GP, PW and VA significantly increased $(\mathrm{p}<0.05)$ the total feed intake compared to control group at 22 to 42 days. Feed efficiency was not significantly affected $(p=0.891)$ by diet throughout the experimental period.

The fatty acids composition of breast muscle is presented in Table 3. Chicken fed with pennywort diet had highest level of C18:3n-3 compared to other dietary treatments $(p<0.05)$. The ratio of $n-6: n-3$ was higher in VM 
Table 2. Effect of dietary supplement on body weight, daily gain, feed intake and feed efficiency (gain:feed) in broiler chickens

\begin{tabular}{|c|c|c|c|c|c|c|}
\hline \multirow{2}{*}{ Parameter } & \multicolumn{4}{|c|}{ Experimental diets } & \multirow{2}{*}{ SEM } & \multirow{2}{*}{$\mathrm{p}$ value } \\
\hline & Control & GP & PW & $\mathrm{VM}$ & & \\
\hline \multicolumn{7}{|l|}{$\overline{\mathrm{BW}}$ (g/bird) } \\
\hline Day 0 & 47.9 & 48.9 & 47.7 & 47.2 & 0.24 & 0.081 \\
\hline Day 7 & 165.1 & 165.4 & 165.4 & 169.4 & 0.91 & 0.272 \\
\hline Day 14 & 355.7 & 360.7 & 363.6 & 366.1 & 2.22 & 0.377 \\
\hline Day 21 & $762.4^{\mathrm{b}}$ & $787.7^{\mathrm{a}}$ & $797.4^{\mathrm{a}}$ & $800.1^{\mathrm{a}}$ & 4.35 & 0.008 \\
\hline Day 28 & $1,199.4^{\mathrm{b}}$ & $1,235.1^{\mathrm{ab}}$ & $1,246.3^{\mathrm{a}}$ & $1245.8^{\mathrm{a}}$ & 7.43 & 0.008 \\
\hline Day 35 & $1,649.2^{\mathrm{b}}$ & $1,709.2^{\mathrm{a}}$ & $1,727.1^{\mathrm{a}}$ & $1,725.3^{\mathrm{a}}$ & 9.52 & 0.011 \\
\hline Day 42 & $2,147.7^{\mathrm{b}}$ & $2,236.8^{\mathrm{a}}$ & $2,258.0^{\mathrm{a}}$ & $2,256.3^{\mathrm{a}}$ & 10.62 & 0.0005 \\
\hline \multicolumn{7}{|c|}{ Daily gain (g/d) } \\
\hline Day 1-21 & 34.02 & 35.18 & 34.90 & 35.22 & 0.29 & 0.419 \\
\hline Day $22-42$ & $45.15^{\mathrm{b}}$ & $47.70^{\mathrm{a}}$ & $48.17^{\mathrm{a}}$ & $48.12^{\mathrm{a}}$ & 0.36 & 0.008 \\
\hline Day 1-42 & $49.99^{b}$ & $52.09^{\mathrm{a}}$ & $52.63^{a}$ & $52.59^{\mathrm{a}}$ & 0.25 & 0.0005 \\
\hline \multicolumn{7}{|c|}{ Feed intake (g/bird) } \\
\hline Day 1-21 & 364 & 372 & 376.3 & 378.1 & 6.97 & 0.164 \\
\hline Day $22-42$ & $893.67^{\mathrm{b}}$ & $945.73^{\mathrm{a}}$ & $956.73^{\mathrm{a}}$ & $954.96^{\mathrm{a}}$ & 12.67 & 0.0005 \\
\hline Day 1-42 & $3,774.0^{\mathrm{b}}$ & $3,953.5^{\mathrm{a}}$ & $3,999.2^{\mathrm{a}}$ & $3,999.2^{\mathrm{a}}$ & 14.06 & $<0.0001$ \\
\hline \multicolumn{7}{|c|}{ Gain:feed (g/g) } \\
\hline Day 1-21 & 0.82 & 0.82 & 0.82 & 0.82 & 0.02 & 0.910 \\
\hline Day $22-42$ & 0.59 & 0.59 & 0.59 & 0.59 & 0.02 & 0.944 \\
\hline Day 1-42 & 0.57 & 0.57 & 0.57 & 0.57 & 0.01 & 0.891 \\
\hline
\end{tabular}

$\mathrm{GP}=$ Garlic powder. $\mathrm{PW}=$ Pennywort powder; VM = Virginiamycin. Data presented as means with pooled SEM ( $\mathrm{n}=6 /$ treatment group).

${ }^{a, b}$ Means within a row with no common superscript differ significantly $(p<0.05)$.

group compared to PW $(\mathrm{p}<0.05)$. Diet had no significant major contributors to the overall PUFA (polyunsaturated effect ( $p>0.05$ ) on the percentage of SFA, UFA and MUFA. fatty acid) of the breast muscle.

The long chain 22-carbon n-3 and 18-carbon n-6 were the Feeding chicks GP, PW, and VM significantly reduced

Table 3. Effect of dietary supplement on fatty acid composition in breast muscle of broiler chickens

\begin{tabular}{|c|c|c|c|c|c|c|}
\hline Fatty acids & Control & $\overline{\mathrm{GP}}$ & $\overline{P W}$ & $\mathrm{VM}$ & SEM & $\mathrm{p}$ value \\
\hline $\mathrm{C} 14: 0^{\text {ns }}$ & 0.40 & 0.51 & 0.56 & 0.62 & 0.04 & 0.312 \\
\hline $\mathrm{C} 16: 0^{\mathrm{ns}}$ & 23.60 & 23.71 & 23.44 & 23.27 & 1.05 & 0.848 \\
\hline $\mathrm{C} 16: 1^{\mathrm{ns}}$ & 3.11 & 3.48 & 3.23 & 4.01 & 0.22 & 0.276 \\
\hline C18:0 $0^{\mathrm{ns}}$ & 11.25 & 11.34 & 10.44 & 10.37 & 0.54 & 0.615 \\
\hline $\mathrm{C} 18: 1^{\mathrm{ns}}$ & 34.86 & 33.25 & 35.86 & 34.00 & 1.59 & 0.426 \\
\hline$C 18: 2 n-6^{\text {ns }}$ & 17.27 & 17.52 & 16.94 & 17.26 & 0.77 & 0.764 \\
\hline C18:3n-3 & $0.58^{\mathrm{b}}$ & $0.60^{\mathrm{b}}$ & $0.87^{\mathrm{a}}$ & $0.50^{\mathrm{b}}$ & 0.05 & 0.007 \\
\hline$C 20: 4 n-6^{\text {ns }}$ & 6.11 & 6.53 & 5.50 & 7.15 & 0.40 & 0.319 \\
\hline$C 20: 5 n-3^{\text {ns }}$ & 0.66 & 0.61 & 0.80 & 0.52 & 0.05 & 0.182 \\
\hline$C 22: 5 n-3^{n s}$ & 0.93 & 1.07 & 0.91 & 1.03 & 0.07 & 0.754 \\
\hline$C 22: 6 n-3^{\text {ns }}$ & 1.20 & 1.34 & 1.39 & 1.23 & 0.07 & 0.607 \\
\hline $\mathrm{SFA}^{1, \mathrm{~ns}}$ & 35.25 & 35.57 & 34.46 & 34.27 & 1.55 & 0.432 \\
\hline $\mathrm{UFA}^{2, \mathrm{~ns}}$ & 64.74 & 64.42 & 65.53 & 65.72 & 2.88 & 0.432 \\
\hline MUFA $^{3, \text { ns }}$ & 37.98 & 36.73 & 39.09 & 38.01 & 1.74 & 0.629 \\
\hline PUFA n- $3^{4, n s}$ & 3.37 & 3.63 & 3.98 & 3.29 & 0.19 & 0.205 \\
\hline PUFA n- $6^{5, \mathrm{~ns}}$ & 23.38 & 24.05 & 22.45 & 24.41 & 1.09 & 0.315 \\
\hline$n-6: n-3$ & $7.20^{\mathrm{ab}}$ & $6.79^{\mathrm{ab}}$ & $5.83^{\mathrm{b}}$ & $7.65^{\mathrm{a}}$ & 0.37 & 0.046 \\
\hline UFA:SFA ${ }^{\mathrm{ns}}$ & 1.85 & 1.81 & 1.94 & 1.92 & 0.08 & 0.459 \\
\hline PUFA:SFA ${ }^{\mathrm{ns}}$ & 0.76 & 0.78 & 0.76 & 0.81 & 0.04 & 0.590 \\
\hline
\end{tabular}

GP = Garlic powder. $\mathrm{PW}=$ Pennywort powder; VM = Virginiamycin.

${ }^{1} \mathrm{SFA}=$ sum of $\mathrm{C} 14: 0+\mathrm{C} 16: 0+\mathrm{C} 18: 0 .{ }^{2} \mathrm{UFA}=$ sum of $\mathrm{C} 16: 1+\mathrm{C} 18: 1+\mathrm{C} 18: 2 \mathrm{n}-6+\mathrm{C} 18: 3 \mathrm{n}-3 .{ }^{3} \mathrm{MUFA}=$ sum of $\mathrm{C} 14: 1+\mathrm{C} 16: 1+\mathrm{C} 17: 1+\mathrm{C} 18: 1 \mathrm{n}-9$.

${ }^{4}$ PUFA n-3 = sum of C18:3n-3. ${ }^{5}$ PUFA n- $6=$ sum of C18:2n- $6 .{ }^{6}$ n-6:n-3 = sum of $(C 18: 2 n-6) /$ sum of $(C 18: 3 n-3)$.

Data presented as means with pooled SEM $\left(n=10 /\right.$ treatment group). ${ }^{\mathrm{a}, \mathrm{b}}$ Means within a row with no common superscript differ significantly ( $\left.\mathrm{p}<0.05\right)$. 


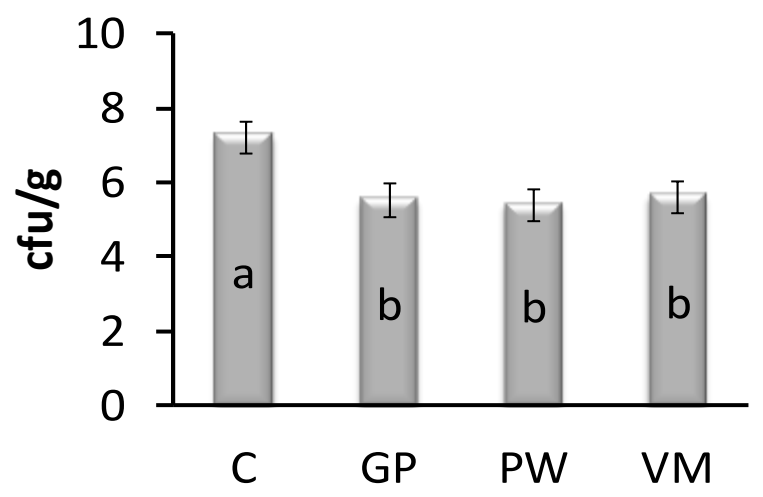

Figure 1. Effect of dietary supplement on intestinal Escherichia coli count in broiler chickens. Data presented as means with pooled SEM (0.25), $\mathrm{n}=10$ /per treatment group. ${ }^{\mathrm{a}, \mathrm{b}}$ Means within a row with no common superscript differ significantly $(\mathrm{p}=0.046)$. $\mathrm{C}=$ Control, $\mathrm{GP}=$ Garlic powder. $\mathrm{PW}=$ Pennywort powder, $\mathrm{VM}$ = Virginiamycin.

Escherichia coli count in the gut when compared to controls on day 42 (Figure 1). On day 42, the intestinal Lactobacillus spp counts of GP, PW and VM chicks were significantly higher $(\mathrm{p}=0.007)$ than the control group (Figure 2). Diet had no significant effect $(\mathrm{p}=0.841)$ on mortality rate (Figure 3).

\section{DISCUSSION}

A number of studies have shown that inclusion of virginiamycin may improve growth performance of broiler chickens (Miles et al., 1984; Beelay et al., 1994). On the contrary, Proudfoot et al. (1990) showed that supplementing broiler chickens with virginiamycin had negligible effect on growth performance. Earlier report (Slyranda et al., 2011) suggested that the effect of garlic supplementation on growth performance in broilers is inconsistent. Demir et al.

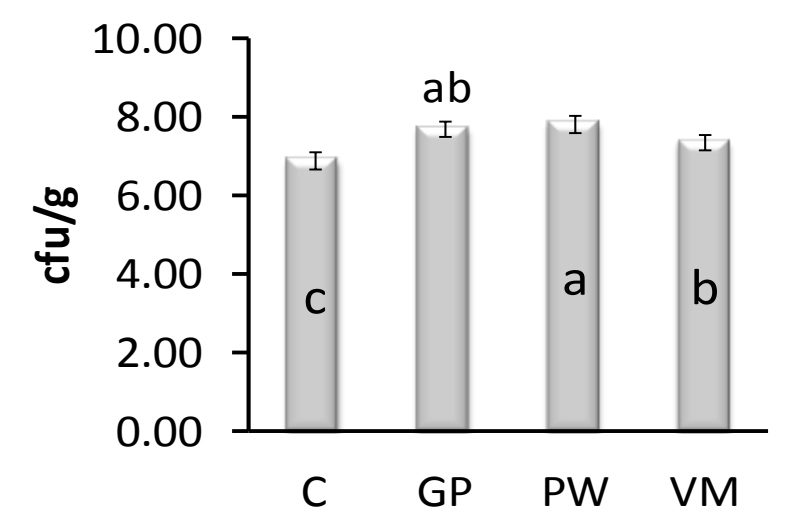

Figure 2. Effects of dietary supplement on Lactobacillus count in broiler chickens. Data presented as means with pooled SEM (0.007), $\mathrm{n}=10$ /per treatment group. ${ }^{\mathrm{a}, \mathrm{b}}$ Means within a row with no common superscript differ significantly $(\mathrm{p}=0.003)$. $\mathrm{C}=$ Control, GP = Garlic powder. PW = Pennywort powder, $\mathrm{VM}=$ Virginiamycin.

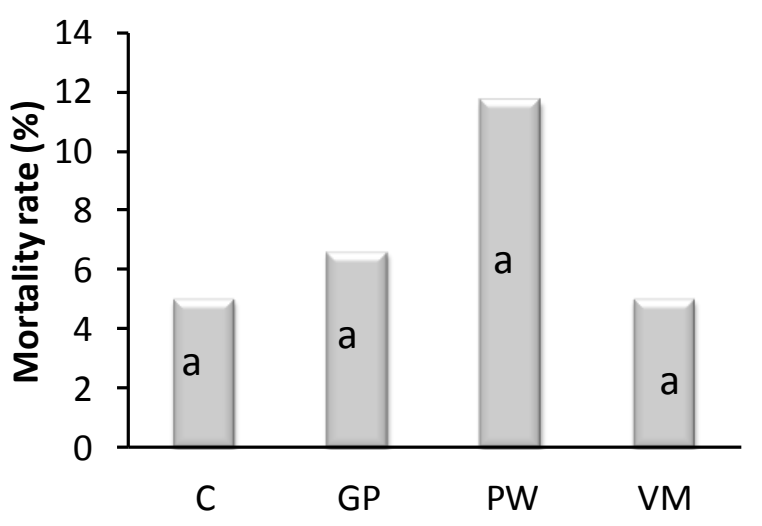

Figure 3. Effect of dietary supplement on mortality rate. ${ }^{a, b}$ Means within a row with no common superscript differ significantly ( $\mathrm{p}=$ 0.841). $\mathrm{n}=60 /$ per treatment group. $\mathrm{C}=$ Control, $\mathrm{GP}=$ Garlic powder. $\mathrm{PW}=$ Pennywort powder, $\mathrm{VM}=$ Virginiamycin.

(2003) and Pourali et al. (2010) reported that garlic supplementation at $0.2,0.4,0.6$, and $1.0 \%$ had negligible influence on growth performance. On the contrary, Kumar et al. (2010) reported that supplementing broilers with garlic based growth promoter at $250 \mathrm{ppm}$ improved BW and FCR. The present findings clearly suggested that birds fed diets supplemented garlic had higher feed intake and greater BW than controls. Improvement in BW could be due to flavouring compound in garlic which attributed the chickens to consume more, hence leading to higher body weight. According to Qureshi et al. (1983), inclusion of garlic more than $0.6 \%$ reduced feed intake and weight gain. It appears that the effectiveness of dietary garlic supplementation in improving growth is dose dependent.

There is very little information available with regards to pennywort supplementation and growth performance in broilers. The only reported work on dietary pennywort supplementation and BW in broilers was by Pongmanee (2003). The author found that broilers supplemented with $1.67 \mathrm{~g} / \mathrm{kg}$ feed of crude powder and $0.40 \mathrm{~g} / \mathrm{kg}$ of crude extract of Asiatic pennywort had significantly greater weight gains than those of controls on day 21 but not on day 42. The present work showed that supplementing diets with pennywort at $0.5 \%$ resulted in greater $\mathrm{BW}$ and higher feed intake than control birds on 22 to 42 days. The antimicrobial properties of pennywort have been demonstrated in in vitro studies. Oyedeji et al. (2005) reported that both crude and chromatographic extracts of pennywort showed antibacterial activity against the test isolates indicating the presence of bioactive ingredients for therapeutic purposes.

Under conditions of the study, the growth performance data obtained in the present work are considered comparable with broilers raised under commercial setting. However, feeding broilers pelleted rations may further improve their FCR (Zulkifli and Ramlah, 1998). Based on 
the present findings, it appears that GP, PW and VM are equally effective in improving feed intake and weight gain of broilers. The FCR for GP, PW and VM were not significantly different $(\mathrm{p}>0.05)$. This may suggested that the response of chickens to growth promoters could be related to genetic background (Miles et al., 1984; Butaye et al., 2003)

The microbial population in the gastrointestinal tract of poultry plays an important role in normal digestive processes and health maintenance (Woods et al., 1999). The present findings suggested that GP, PW and VM are able to reduce intestinal Escherichia coli counts in broilers. Similarly, Kumar et al. (2010) indicated that the inclusion of garlic at $250 \mathrm{ppm}$ in the broiler diet reduced the count of Escherichia coli as well as reduction of Salmonella when compared to control group. In vitro studies suggested that the antibacterial property of garlic is attributed to allicin compound (Ankri and Mirelman, 1999; Willis and Reid, 2003). The present study also demonstrated that dietary supplementation of pennywort may also reduce Escherichia coli count in the gut. According to Norzaharaini et al. (2011), the antibacterial effect of pennywort was derived from bioactive compound, asiaticoside.

The benefits of lactic acid bacteria (LAB), such as Lactobacillus spp, in enhancing growth and immunity of poultry are well documented (Dang and Visek, 1960; Jin et al., 1996). The present findings showed that GP, PW, and VM can improve Lactobacillus count in the gut. The mode of action of LAB includes i) maintaining normal intestinal microflora by competitive exclusion and antagonism; ii) altering metabolism by increasing digestive enzyme activity and decreasing bacterial enzyme activity and ammonia production; iii) improving feed intake and digestion; and iv) neutralizing enterotoxins and stimulating the immune system (Dang and Visek, 1960).

Earlier reports indicated that LAB was resistant to the antimicrobial effects of some herbal plants and spices (Zaika and Kissinger, 1979; Patterson and Burkholder, 2003). In an in vitro study by Rees et al. (1993), suggested that lactic acid bacteria were unaffected by the presence of garlic because the production of lactic acid by LAB reduced the surrounding $\mathrm{pH}$ and subsequently killed Escherichia coli. Combination effect of garlic and pennywort effects could be exploited to maximize the antibacterial activity of herbs. It is known that the antimicrobial property of feed supplements is more obvious under less hygienic condition (Barrows, 1992).

There is considerable evidence (Qureshi et al., 1983) suggesting that dietary garlic supplementation can reduce lower palmitic acid, SFA, serum and meat cholesterol content and increase unsaturated fatty acids (UFA) in chickens. Compounds such as allyl-disulfide or allylsulfhydryl groups could be responsible for the inhibition of cholesterol synthesis by garlic (Singh and Porter, 2006).

In the present study, we have been using $0.5 \%$ of garlic of which it is reasonable to surmise that the inclusion of the garlic might have some beneficial effect on chickens' meat with increased level of garlic supplement in diet as showed by Onibi et al. (2009). Increasing level of garlic in diet may have influence on fatty acid profile in chickens' meat.

Hussin et al. (2009) reported that pennywort-fed rats had elevated high-density lipoprotein (HDL) and decreased triglyceride level than those fed control diet. The increase in HDL will result in higher antiatherogenic index and HDLcholesterol/total cholesterol ratio. Hence, pennywort has the potential to control the formation of atherosclerosis and coronary heart disease in rats (Hussin et al., 2009). Nevertheless, pennywort contained high levels of omega-3 fatty acid of fatty acid composition $3.98 \%$ compared to garlic which might increase the omega-3 fatty acid composition in meat by increasing the amount of supplementation.

\section{CONCLUSIONS}

This study demonstrated that dietary supplementation of garlic, and pennywort may improve the growth performance of broilers. Reduction of Escherichia coli and increase of Lactobacillus in the small intestine by adding garlic and pennywort in basal diet could be commercially interesting as it may have the potential to be an alternative to antibiotic growth promoter for broiler chickens. Hence, the beneficial effect of pennywort and garlic supplementation in improving growth performance of broiler chickens may be more obvious under floor pen system as compared to cages which are considered more hygienic. Further research is required to evaluate the effects of garlic and pennywort on fatty acid composition in chickens' meat.

\section{ACKNOWLEDGEMENT}

The research was supported by Universiti Putra Malaysia. A special thanks to Prof. Saleha Abdul Aziz, Ms. Krishnammah Kuppusamy and Ms. Fauziah Nordin for their technical assistance during the experimental period.

\section{REFERENCES}

Amagase, H., B. Petesch, H. Matsuura, S. Kasuga, and Y. Itakura. 2001. Recent advances on the nutritional effects associated with the use of garlic as a supplement: Intake of garlic and its bioactive components. J. Nutr. 131: 955S-962S.

Ankri, S. and D. Mirelman. 1999. Antimicrobial properties of allicin from garlic. Microbes Infect. 1:125-129.

Barrows, P. A. 1992. Probiotics for chickens. In: Probiotics- The scientific basis (Ed. R. Fuller). Chapman \& Hall, London: 234.

Beelay, T. and R. Teeter. 1994. Virginiamycin effects on 
performances and saleable carcass of broilers. J. Appl. Poult. Res. 3:111-116.

Bourre, J. 2005. Where to find omega-3-fatty acids and how feeding animals with diet enriched in omega-3-fatty acids to increase nutritional value derived products for human: What is actually useful? J. Nutr. Health Aging 9:232-242.

Butaye, P., L. A. Devriese, and F. Haesebrouck. 2003. Antimicrobial growth promoters used in animal feed: Effects of less well known antibiotics on gram-positive bacteria. Clin. Microbiol. Rev. 16:175-188.

Chang, K. and S. Cheong. 2008. Volatile organosulfur and nutrient compund from garlic by cultivating areas and processing methods. Fed. Am. Soc. Exp. Bio. J. 22:1108-1112.

Cross, D., R. K. H. Mcdevitt, and T. Acamovic. 2007. The effect of herbs and theirassociated essential oils on performance, dietary digestibility and gut microflora in chickens from 7 to 28 days of age. Br. Poult. Sci. 48:496-506.

Cruz, R., S. Casal, E. Mendes, A. Costa, C. Santos, and S. Morais. 2013. Validation of a single-extraction procedure for sequential analysis of vitamin e, cholesterol, fatty acids, and total fat in seafood. Food Anal. Methods 6:1196-1204.

Dang, H. C. and W. J. Visek. 1960. Effect of urease injection on body weights of growing rats and chicks. Exp. Biol. Med. 105: 164-167.

Demir, E., S. Sarica, M. A. Ozcan, and M. Suicmez. 2003. The use of natural feed additives as alternatives for an antibiotic growth promoter in broiler diet. Br. Poult. Sci. 44:44-45.

Ebrahimi, M., M. A. Rajion, Y. M. Goh, and A. Q. Sazili. 2012. Impact of different inclusion levels of oil palm (Elaeis guineensis Jacq.) fronds on fatty acid profiles of goat muscles. J. Anim. Physiol. Anim. Nutr. 96:962-969.

Folch, J., M. Lees and G. Sloane-Stanley. 1957. A simple method for the isolation and purification of total lipids from animal tissues. J. Biol. Chem. 226: 497-509.

Hussin, M., A. Abdul-Hamid, S. Mohammad, N. Saari, M. Ismail, and M. Bejo. 2007. Protective effect of Centella asiatica extract and powder on oxidative stress in rats. Food. Chem. 100:535-541.

Hussin, M., A. Hamid, S. Mohamad, N. Saari, F. Bakar, and S. Dek. 2009. Modulation of lipid metabolism by Centella asiatica in oxidative stress rats. J. Food Sci. 74:H72-H78.

Inamdar, P., R. Teola, A. Ghogare, and N. de Souza. 1996. Determination of biologically active constituents in Centella asiatica. J. Chromatogr. A 742:127-130.

Jin, L. Z., Y. W. Ho, N. Abdullah, and S. Jalaludin. 1996. Influence of dried Bacillus subtilis and lactobacilli cultures on intestinal microflora and performance in broilers. Asian-Aus. J. Anim. Sci. 9:397-403.

Kumar, M. and J. S. Berwal. 1998. Sensitivity of food pathogens to garlic (Allium sativum). J. Appl. Microbiol. 84:213-251.

Kumar, S., K. Sharadamma, and P. Radhakrishna. 2010. Effects of garlic active based growth promoter on growth performance and specific pathogenic intestinal microbial counts of broiler chicks. Int. J. Poult. Sci. 9:244-246.

Miles, R., D. Janky, and R. Harms. 1984. Virginiamycin and broiler performances. Poult. Sci. 63:1218-1221.

Miles, R. D., G. D. Butcher, P. R. Henry, and R. C. Littell. 2006. Effect of antibiotic growth promoters on broiler performance, intestinal growth parameters and quantitative morphology.
Poult. Sci. 85:476-485.

National Research Council. 1994. Nutrient requirements of poultry. 9th Rev. Ed. NAS-NRC, Washington, DC.

Nisha, A. R. 2008. Antibiotic residue - A global health hazard. Vet. World 1:375-377.

Norzaharaini, M., W. S. Norshazwani, A. Hasmah, N. Nor Izani, and S. Rapeah. 2011. A preliminary study on the antimicrobial activities of asiaticoside and asiatic acid against selected gram positive and gram negative bacteria. Health. Environ. J. 2:2326.

Onibi, G. E., E. A. Oluwatoyin, N. F. Adebowale, and V. A. Ayodeji. 2009. Response of broiler chickens in terms of performance and meat quality to garlic (Allium sativum) supplementation. African J. Agric. Res. 4:511-517.

Oyedeji, O. A. and A. J. Afolayan. 2005. Chemical composition and antibacterial activity of the essential oil of Centella asiatica growing in South Africa. Pharm. Biol. 43:249-252.

Patterson, J. A. and K. M. Burkholder. 2003. Application of prebiotics and probiotics in poultry production. Poult. Sci. 82: 627-631.

Pongmanee, K. 2003. Effects of asiatic pennywort (Centella asiatica I. Urban) leaves a replacement of antibiotic, on growth performance, mucosal enzyme activities of the small intestine and nutrient digestibility in broiler chickens. MS Thesis, Chulalongkorn University, Thailand. http://lib.vet.chula.ac.th/ Data_files/ebook/Thesis/Thesis2536-2547/CD_Thesis /176.pdf. Accessed on 10/6/2011.

Pourali, M., S. Mirghelenj, and H. Kermanshahi. 2010. Effects of garlic powder on productive performance and immune response of broiler chickens challenged with Newcastle Disease virus. Glo. Vet. 4:616-612.

Proudfoot, F. G., E. D. Jackson, and H. W. Hulan. 1990. The response of male chicken broilers to the dietary addition of VRG. Poult. Sci. 69:1713-1717.

Qureshi, A. A., N. Abuirmeile, Z. Z. Din, C. E. Elson, and W. C. Burger. 1983. Inhibition of cholestrol and fatty acid biosynthesis in the liver enzymes and chicken hepatocytes by polar fractions of garlic. Lipids 18:343-348.

Rees, L. P., S. F. Minney, N. T. Plummer, J. H. Slater, and D. A. Skyrme. 1993. A quantitative assessment of the antimicrobial activity of garlic (Allium sativum). World J. Microbiol. Biotechnol. 9:303-307.

Rumalla, C., Z. Ali, A. Weerasooriya, T. Smillie, and I. Khan. 2010. Two new triterpene glycosides from Centella asiatica. Planta Med. 76:1018-1021.

Singh, D. and T. Porter. 2006. Inhibition of sterol 4alphamethyloxidase is the principal mechanism by which garlic decreases cholestrol synthesis. J. Nutr. 136:759S-764S.

Slyranda, B. A., I. A. Y. Kennedy, B. N. Joel, A. Auwal, A. Usman, A. I. Muhammed, A. Haruna, M. B. Mohammed, M. I. Hama'Adama, and T. N. Patric. 2011. Effects of feeding onion (Allium cepa) and garlic (Allium sativum) on some performance characteristics of broiler chickens. Res. J. Poult. Sci. 4:22-27.

Tipu, M. A., M. S. Akhtar, M. I. Anjum, and M. L. Raja. 2006. New dimension of medicinal plants as animal feed. Pak. Vet. J. 26:144-148.

William, P. and R. Losa. 2001. The use of essential oils and their compounds in poultry nutrition. World Poult Sci. 17:14-15. 
Willis, W. and L. Reid. 2008. Investigating the effects of dietary probiotic feeding regimens on broiler chicken production and campylobacter jejuni presence. Poult. Sci. 87:606-611.

Wood, J. D., M. Enser, G. Nute, R. Richardson, and P. Sheard. 1999. Manipulating meat quality and composition. Proc. Nutr. Soc. 58:363-370.

Yalcin, S., I. Onbaslar, A. Sehu, and S. Yalcin. 2007. The effect of dietary garlic powder on the performance, egg triats and blood serum cholesterol of laying quails. Asian-Aust. J. Anim. Sci. 20:944-950.
Zaika, L. L. and J. C. Kissinger. 1979. Effects of some spices on acid production by starter cultures. J. Food Prot. 42:572-576.

Zulkifli, I., S. R. Hasheimi, M. N. Somchit, Z. Zunita, T. C. Loh, A F. Soleimani, and S. C. Tang. 2012. Effects of Euphorbia hirta and virginiamycin supplementation on performance, digestibility, and intestinal microflora population in broiler chickens. Arch. Geflüg. 76:6-12.

Zulkifli, I. and A. H. Ramlah. 1998. Biological and economic performances of broiler chickens fed mashed or pelleted diet. Malays. Appl. Bio. 27:21-24. 